Chapter 5

\title{
Mineral Composition of Blood Sausages - A Two-Case Study
}

\author{
Daphne D. Ramos, Luz H. Villalobos-Delgado, \\ Enrique A. Cabeza, Irma Caro, \\ Ana Fernández-Diez and Javier Mateo \\ Additional information is available at the end of the chapter \\ http://dx.doi.org/10.5772/53591
}

\section{Introduction}

\subsection{Relevance of the assessment of mineral content in food}

It is well known that a balanced diet is essential in maintaining a good health; hence, the nutritional value of foods is an important aspect of food quality [1]. In this context, more and more people are becoming very concerned about the chemistry of what they eat. Consequently, food industry is interested in maintaining a high standard of quality of their manufactured products which could meet the demands of an increasingly sophisticated consumer. Therefore, an important issue of food industry is the determination of food composition and the establishment of analytical controls [2].

Food scientists and food industry have long since been paying great attention to minerals in food, which has been mainly devoted to its essential role in human nutrition, i.e., physiological functions, humans' nutritional requirements, and mineral implication on safeness issues, i.e., mineral toxicity. There are more than 60 minerals in the human body, but only a few are considered to be essential, namely, iron, calcium, zinc, magnesium, phosphorus, sodium, potassium, manganese, selenium, copper. These minerals are absolutely essential to a host of vital processes, from bone and tooth formation, to the functioning of neurological, circulatory, renal and digestive systems, and some of them are necessary for regulation of enzyme systems $[2,3]$.

Minerals deficiencies in human are common world-wide and there are evidences which suggest that deficiencies may play a main negative role in children's development, pregnancy 
and elderly health [3]. In this context, $\mathrm{Ca}, \mathrm{K}, \mathrm{Mg}$ and Fe are the most commonly under-consumed minerals in humans' diet [4]. Fe deficiency is the most common and widespread nutritional disorder in the world affecting both developing and industrialized nations [5]. Insufficient intakes of Fe cause anemia, fatigue, poor growth, rickets and impaired cognitive performance in humans [3]. On the other hand, the concentration of non-desired minerals in food can be increased by the persistent release of hazardous pollutants to the environment mainly derived from human industrial activity. This contamination of food supply can result in an increase of exposure of consumers to toxic metals such as lead, cadmium, arsenic and mercury, to levels higher than the tolerable daily intake [6].

The assessment of the mineral content in food is not only interesting from the nutritional and toxicological points of view. Since a few decades ago, instrumental analytical techniques based on atomic absorption or emission spectrometry applied to the determination of the mineral content coupled to multivariate statistical analysis have been proved to produce suitable methods to characterise food products, discriminate between food quality categories and control food authenticity, i.e., determination of the geographical origin of food, discrimination between cultivation methods (e.g. organic vs convenience crops), varieties of fruits and vegetables, or food processing practices [7-10].

The analysis of minerals in foods is challenging due to the wide range of concentrations present, which may vary from ppb to percent levels. The situation is further complicated by naturally occurring seasonal and varietal differences in concentrations within the same food [11]. Official methods by de AOAC offers many single element methods based on colorimetric techniques: UV/Visible spectrophotometry, and flame and graphite furnace atomic absorption spectrophotometry. However, although no AOAC food methods currently employ Inductively Coupled Plasma-Atomic Emission Spectroscopy (ICP-AES), it is a well-established multi-element technique that no requires the use of dangerous solvents from the environmental point of view [11]. Its high specificity, multi-element detection capability and good detection limits result in the use of this technique in a large variety of applications. Detection limits typically range from parts per million (ppm) to parts per billion (ppb), although depending on the element and instrument, it can sometimes achieve even less than ppb detection [12]. ICP-AES provides higher reproducibility and quantitative linear range compared to conventional AES, and reduces molecular interferences due to a higher temperature $(7000-8000 \mathrm{~K})$ in the excitation source (plasma). On the other hand, ICP-AES is more expensive than conventional AES, and in complex samples, emission patters can be of difficult interpretation [13].

\subsection{Blood sausages, making process and chemical composition}

Meat products are generally made from various raw materials (from different origins and suppliers), which are combined at the formulation stage in obedience to criteria of composition, technological factors, sensory characteristics, legal regulations and also economic efficiency and profit [14].

Among meat and meat products, muscle foods are the most commonly consumed. However several edible meat by-products and their derivatives are also importantly consumed in a 
number of countries, where meat by-products are usually linked to traditional or ethnic foods. Meat by-products are traditionally sold to the lower income market however, by different reasons - one of them could be the increase in tourism - their consumption seems to be increasing and some of the by-products are becoming delicacies in niche markets. Advantageously, meat by-products consumption contributes to increase the edible portion of slaughter animals, Furthermore, meat edible by-products constitute an excellent source of nutrients like essentials amino acids, minerals and vitamins $[15,16]$. Due to the great variety and specificity of edible meat by-products and their peculiar consumption patterns and their relative low economic value, there is relatively scarce information on their making process and chemical composition.

In some areas of the world, and to different degrees, blood is utilized as an edible meat byproduct. For example, for several ethnic groups of Africa and India, blood is the primary source of animal protein, where it holds ritualistic importance. However, in some cultures (Islamic and Jews), blood consumption is seen as a taboo [17,18]. In Europe and Asia, animal blood has been traditionally used in making a variety of foods such as blood sausages, blood pudding, biscuits and bread, as well as blood soups and crackers $[19,20]$.

From the nutritional point of view, blood is a good source of dietary protein, lysine and iron $[19,21]$. The high iron content of blood (approximately between 400-500 $\mathrm{mg}$ of iron per liter), coupled with the high absorption of heme iron compared to non-heme iron, is particularly useful for food based strategies designed to combat iron deficiency anemia. Furthermore, the environmental concern associated with blood disposal at slaughterhouses, together with blood nutritive value, has fostered research and industrial efforts to recover blood or blood components, to be used into a wide range of food products or as dietary supplements [22]. For example, blood or blood proteins (plasma or cellular fractions) are being used in meat products, primarily to increase protein levels and enhance water binding and emulsifying capacity.

Blood sausages are very popular traditional meat products in many parts of the world such as Europe, Latin America or Asia [23-26]. In Europe, blood sausages are normally called morcilla and morcella in Spain and Portugal, black pudding in Great Britain, blutwurst and Thuringer blood sausage in Germany, blodp $\phi l s e$ in Denmark, boudin noir in France, bloed worst in Belgium, blood-tongue sausage and black pudding in Austria, caltabosi cu singe in Hungary, vaerevorst in Estonia, kaszanka in Poland, biroldo in Italy. In Latin American countries, blood sausages are also produced and are named as relleno, prieta, moronga, mocillón in Mexico, Colombia, Peru or Argentina, and Morcela in Brazil; these sausages from Latin America show characteristics similar to those from Europe, especially to those of Iberian Peninsula [25]. In this sense, blood sausages from Latin America can be included into the group of creole meat products, which means that they were originated from the adaptation of former Iberian meat products (brought to America by immigrants) to local condition and circumstances, thus, involving an innovation process at that time.

Nowadays, blood sausages are currently receiving worldwide increasing attention because they have become gourmet products in several countries, thus leading to an increase in their production and potential markets [27]. Furthermore, increasing consumer demand for eth- 
nic specialties has renewed interest in such products, leading to a consequent need to assure safety and longer shelf-lives in an expanding market. Moreover, the Governmental Institutions, e.g., European Union, are getting more involved in the protection of high-quality traditional foods from specific regions or areas, which reflects a policy of supporting the inhabitants of rural areas and promoting regional products [23,27].

Blood sausages are basically made with blood, fat and a variety of vegetable origin food; Moreover the use of meat, pork skin or offal (e.g., liver, intestine) is common, mainly in German blood sausages [28-31]. The vegetable-origin food used is enormously diverse so that, apart from spices and condiments, blood sausages can contain as main ingredients onion, leeks, cereals (rice, oat, flour, bread, etc.), sugar, fruits (apple, plum, etc.), nuts, etc. [32-34]. Other ingredients such as eggs, cream, milk are used in some types of blood sausages in France [32]. Moreover, as any meat product, blood sausages are added with common salt. The $\mathrm{NaCl}$ used in blood sausages from Mediterranean Europe tend to be between 1.2 and $1.5 \%$ [35-37], and in blood sausages from Germany [38] and USA [16] tend to be higher, close to $2 \%$. NaCl has a direct effect on the flavour and also increases the shelf-life, decreasing the water activity. Finally, several additives such as curing agents (nitrate and nitrite salts), $\mathrm{pH}$ modifiers (such as lactate or acetate salts) or emulsifiers can be also used [30,39].

The making process of blood sausages differs as a result of type, region and manufacturer. However, a common flow chart of the process of most of the blood sausages is depicted in Table 1 [21]. The initial mixture of blood sausages is complex by the number of ingredients used and pre-treatments to which those ingredients have been undergone. For example, meat can be cured previously to the mixture preparation, or pork rind can be cooked and emulsified. Similarly, several ingredients, such as fat, onion or rice, can be cooked before the mixture is prepared. Once prepared, the initial mixture is normally stuffed into natural or artificial casings and the sausage is cooked in hot water until a temperature of $65-75{ }^{\circ} \mathrm{C}$ is reached in the inner part of it [31], and then the sausage is chilled before refrigeration storage. Some varieties of blood sausages are dried and/or smoked after cooking. Once cooked and chilled, most of blood sausages present a dark-red to black colour and a rather firm and sliceable texture [30] due to the formation of a gel structure from the interaction of collagen, starch, blood proteins, etc.; nonetheless, some blood sausages are soft and spreadable.

1. Raw matter selection

2. Preliminary preparation of raw materials (weighting, size reduction, premixing, precooking, curing, etc.)

3. Mixing

4. Stuffing

5. Cooking

6. Chilling

Table 1. General flow chart of blood sausage making process 
In general, meat and meat products are generally recognized as good sources of high biological-value proteins, group B vitamins, minerals as well as some other bioactive compounds [15]. The composition of meat products depends on their formulation. Thus, the chemical composition of blood sausages is diverse and would depend on the ingredients and manufacturing process used. As a matter of reference, Table 2 shows the proximate composition of several blood sausages from Europe and Latin America. Moisture is expressed as percentage of fresh weight, and values of protein, fat, available carbohydrate, fibre and ash are expressed as percentage of dry matter. The literature sources for the data are the following (see Table for superscripts correspondence): a[36], ' $[40],{ }^{c}[38],{ }^{\mathrm{d}}[41], \mathrm{e}[42], \mathrm{f}[35], \mathrm{g}[37], \mathrm{h}[16]$, i[43], i [44].

\begin{tabular}{|c|c|c|c|c|c|c|}
\hline $\begin{array}{c}\text { Location and blood sausage } \\
\text { name }\end{array}$ & Moisture & Protein & Fat & $\begin{array}{c}\text { Available } \\
\text { carbohydrate }\end{array}$ & Fibre & Ash \\
\hline \multicolumn{7}{|l|}{ Europe } \\
\hline De Burgos, Spain ${ }^{a}$ & 62.2 & 13.1 & 28.7 & 51.1 & 1.7 & 4.3 \\
\hline Asturiana, Spain ${ }^{b}$ & 38.5 & 7.0 & 69.1 & 8.0 & - & 2.9 \\
\hline With onion, Spain & 46.0 & 20.9 & 59.4 & 23.2 & 0.0 & - \\
\hline Blutwurst, Germanyc & 55.9 & 27.4 & 65.8 & 0.0 & - & - \\
\hline Thueringer, Germany ${ }^{c}$ & 66.2 & 58.9 & 32.3 & 0.0 & - & - \\
\hline Verivanukas, Finland ${ }^{d}$ & 61.1 & 19.3 & 22.6 & 43.9 & 9.8 & - \\
\hline Verimakkara, Finland ${ }^{d}$ & 54.7 & 28.7 & 42.0 & 21.2 & 6.2 & - \\
\hline Blodpølse, Denmarke & 43.7 & 19.0 & 36.9 & 32.0 & 8.9 & 3.2 \\
\hline With rice, Portugal ${ }^{f}$ & 62.0 & 28.9 & 38.9 & 24.6 & - & - \\
\hline Boudin noir, France ${ }^{g}$ & 62.0 & 26.8 & 58.1 & 10.8 & - & - \\
\hline
\end{tabular}

\section{America}

\begin{tabular}{|c|c|c|c|c|c|c|}
\hline Blood Sausage, USA ${ }^{\text {h }}$ & 47.3 & 27.7 & 65.5 & 2.5 & 0.0 & 4.4 \\
\hline Traditional, Chilei & 77.8 & 47.3 & 38.3 & 0.0 & 5.9 & 8.6 \\
\hline Traditional, Boliviaj & 44.5 & 31.7 & 57.3 & 10.8 & - & 1.8 \\
\hline With tongue, Boliviaj & 48.8 & 41.2 & 55.5 & 0.0 & - & 3.3 \\
\hline Stege, Boliviaj & 41.2 & 31.2 & 56.8 & 6.5 & - & 5.4 \\
\hline
\end{tabular}

Table 2. Proximate composition of several blood sausages from Europe and America

Moisture content of blood sausages would depend inversely on the fat content and directly on the amount of moisture evaporated during an eventual drying/smoking stage. As can be seen in Table 2, the ranges of fat, available carbohydrate and protein in dry matter vary from 22.6 to $69.1,0$ to 51.1 and 7 to 58.9 , respectively. There are great variations in dry matter composition between sausage types, which can be attributable to differences in the quanti- 
ties of the main ingredients used, i.e., pork fat, cereals, vegetables, meat or blood. Thus, the presence and levels of fibre are the result of the use of vegetables, namely onion, leek, fruits, etc. Finally, ash content is related to the amount of common salt used in the making process. Regarding to the mineral content of blood sausages, the Fe content is the most reported in literature. Fe content of blood sausages is high due to the use of blood, and amounts reported vary from 6 to $16 \mathrm{mg}$ per $100 \mathrm{~g}[16,36,42,45]$.

\subsection{Aim of the study}

In spite of their popularity and increasing interest, literature on the composition and quality of blood sausages is to our knowledge scarce. The knowledge of the chemical composition of blood sausages presents potential usefulness regarding nutritional, product characterization and quality control aspects. Among the chemical composition, the mineral content of blood sausages seems to be a key point in those aspects.Therefore, the main aim of the present study is to describe and determine, as case studies, the manufacturing process and the chemical composition with particular interest on the mineral content, of two typical blood sausages produced in two different parts of the world: a typical blood sausage with white onion (Allium cepa), from the region of Leon (north-western Spain), known as Morcilla de Leon; and typical blood sausage with white cabbage (Brassica Oleracea var. capitata), from the region of Tumbes (north-western Peru), known as Relleno de Tumbes.

\section{Material and methods}

\subsection{Making process of the blood sausages}

In order to collect information about the making process of the blood sausage Morcilla de Leon, four interviews were conducted with the correspondent production managers at the four main local companies producing this sausage in Leon city. The two-member interview panel asked a set of questions regarding general company characteristics, raw materials used, making process and storage conditions. Moreover, collecting data on the making process of Relleno de Tumbes was carried out by standardized open-ended interviews conducted with 15 homemade manufacturers at the region of Tumbes (Tumbes city and small villages at Zarumilla province). The questions asked were to know information on the raw materials used and the making process followed. In both cases, the interviews were followed by the observation of the sausage making process.

\subsection{Chemical analysis}

A total of 8 samples of Morcilla de Leon were manufactured by local producers (city of Leon, north-western Spain) and were purchased from local markets. The sample weights were approximately $250 \mathrm{~g}$. Once taken, the sausages were transported under refrigeration $\left(<4{ }^{\circ} \mathrm{C}\right)$ to the laboratory of Department of Food Hygiene and Technology (University of Leon). On the other hand, a total of 12 samples of Relleno de Tumbes were obtained from 
small local producers and retail stores in Tumbes City (north-western Peru) and small villages around the city. For each sausage sampled, a $300 \mathrm{~g}$ sample was packaged individually in a bag and transported in refrigerated containers to the laboratory in Tumbes. Subsequently, samples were frozen at $-40^{\circ} \mathrm{C}$ and were transported to the laboratory at University of Leon where upon arrival at laboratory the samples were kept frozen at $-40{ }^{\circ} \mathrm{C}$ until the analysis was performed.

Determinations of moisture, fat, protein and ash contents in the sausage samples were performed in duplicate according to methods recommended by the AOAC International [46] Official Methods nos. 950.46, 991.36, 981.10 and 920.153, respectively. Total dietary fibre was analysed following the AOAC 991.43 standard method [46], using the K-ACHDF 11/06 enzymatic kit (Megazyme, Wicklow, Ireland). Finally, the percentage of available carbohydrates was calculated by difference (100 - the percentage of the rest of components).

The analysis of mineral composition of sausages was performed by ICP-AES on wet digested samples. Duplicate aliquots of approximately $1 \mathrm{~g}( \pm 0.01)$ of the previously homogenised samples were digested with $10 \mathrm{ml}$ of concentrated $\mathrm{HNO}_{3}$ in tightly closed screw cap glass tubes for $18 \mathrm{~h}$ at room temperature, and then for a further $4 \mathrm{~h}$ at $90{ }^{\circ} \mathrm{C}$. For the analysis of sodium, potassium, sulphur and phosphorus, $1 \mathrm{ml}$ of the mineralized solution was added with $8 \mathrm{ml}$ of deionized water and $1 \mathrm{ml}$ of scandium solution as internal standard. In order to determine the levels of calcium, copper, iron, magnesium, manganese and zinc, $3 \mathrm{ml}$ of the digested solution was added with $6 \mathrm{ml}$ of deionized water and $1 \mathrm{ml}$ of Sc solution.

The instrumental analysis was performed with an Optima 2000 DV ICP optical emission spectrometer (PerkinElmer, Waltham, MA, USA). Instrument operating conditions were: radiofrequency power, $1400 \mathrm{~W}$; plasma gas flow, $15.0 \mathrm{l} / \mathrm{min}$; auxiliary gas flow, $0.2 \mathrm{l} / \mathrm{min}$; nebulizer gas flow $0.75 \mathrm{l} / \mathrm{min}$, crossed flow; standard axial torch with $2.0 \mathrm{~mm}$ i.d. injector of silica; peristaltic pump flow, $1 \mathrm{ml} / \mathrm{min}$; no. of replicates, 2 . The spectrometer was calibrated for $\mathrm{Cu}, \mathrm{Mn}, \mathrm{Zn}, \mathrm{Fe}, \mathrm{Ca}$ and $\mathrm{Mg}$ determinations (at 224.7, 257.61, 213.9, 238.2, 393.4 and 279.6 $\mathrm{nm}$, respectively) with nitric acid/water (1:1, v/v) standard solutions of 2, 5 and $10 \mathrm{ppm}$ of each element, and for $\mathrm{Na}, \mathrm{P}, \mathrm{S}$ and $\mathrm{K}$ (at 589.6, 213.6, 182.0 and 766.5, respectively) with nitric acid/water (1:9, v/v) standard solutions of 30, 50 and 100 ppm, respectively.

\subsection{Statistical analysis}

The software STATISTICA for Windows [47] was used for the statistical treatment of data. Furthermore, a principal component (PC) analysis, unrotated method, using the mineral composition as expressed as non-fat dry matter, was also performed.

\section{Results and discussion}

\subsection{Making process}

The Morcilla de Leon (Figure 1), typically produced in the region of Leon (north-western Spain), is made from a mixture of chopped onion (used at amounts between 65 and $75 \%$ of 
total weight), animal fat (lard and/or tallow; 10-20 \%), blood (normally from pigs, 10-20 \%), rice or breadcrumbs (2-10\%), salt (1-1.5\%), dry powdered paprika (1-2 \%; including hot and sweet paprika), garlic and a mixture of spices (usually up to $1 \mathrm{~g} / \mathrm{kg}$ ) composed of several of the following: oregano, cumin, anis, cinnamon or pepper. Normally, onion and rice are precooked with the lard or tallow for 1-2 hours (until the onion becomes soft and tender). At the end of cooking, the condiments, spices and blood (liquid) are added and the mix is stirred from some minutes. Nevertheless, one manufacturer did not precook the onion and fat, and thus all ingredients (raw) were cold-mixed. The mixture, (hot if it was precooked or cold if not precooked) is stuffed in natural pork or beef casings of around $45 \mathrm{~mm}$ of diameter, tied or clipped forming $20-\mathrm{cm}$ pieces. After the stuffing of the mix, the sausages are cooked in hot water at $80-90{ }^{\circ} \mathrm{C}$ for $20-45 \mathrm{~min}$. After this step, sausages are drained hung at room temperature for a few hours and then chill-stored. This product is usually stored without packaging, and the shelf-life is around 12 days at refrigeration temperatures.

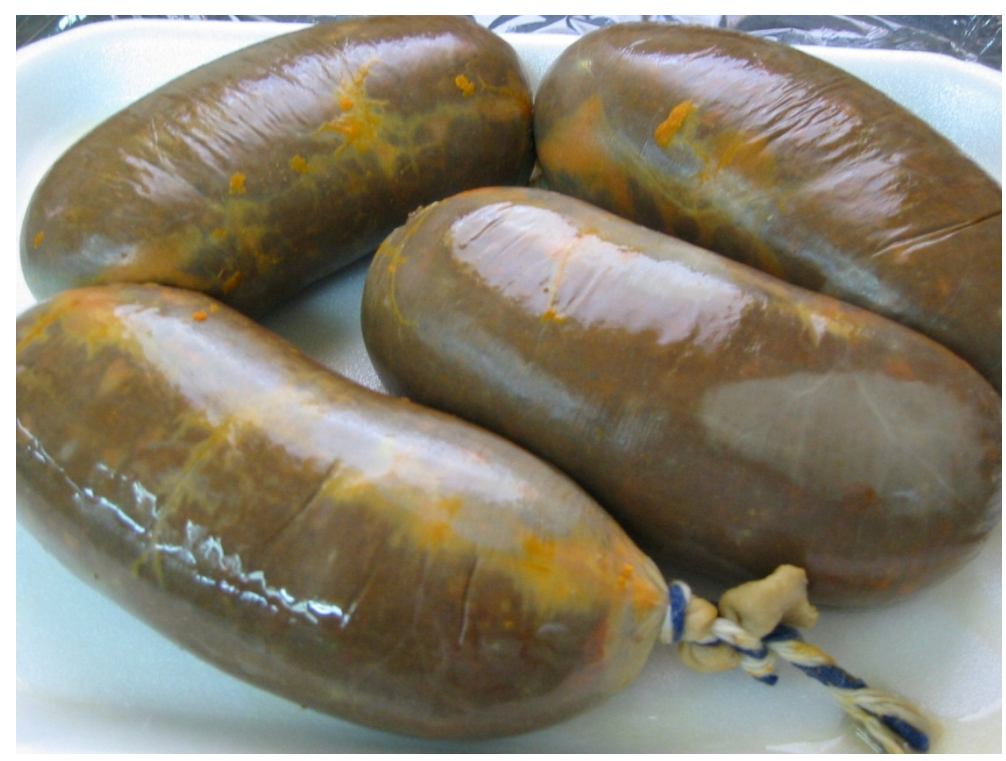

Figure 1. Spanish blood sausage Morcilla de León.

Relleno de Tumbes (Figure 2) is a typical blood sausage from Northern Peru, which consists of a mixture of blood (approximately 30\%), pork lard fat $(10 \%)$, chopped cabbage $(40 \%)$, chopped red and Chinese onion (5\%), chopped fresh paprika ( $2 \%$; including sweet and hot paprika local varieties), common salt (1.5\%) and a number of herbs and spices at low quantities (spearmint, coriander, garlic, cumin, pepper) and a in-situ-prepared annatto oil extract; furthermore, the addition of glutamate is common. The amounts indicated above are roughly estimated because the manufacturers did not use scales and the interviewers did not carry a scale in order to weight the ingredients used in the making process. The blood (liquid or 
coagulated, sometimes precooked and shredded) is manually mixed with the lard, chopped vegetables and salt. Then, the mix is manually stuffed into natural pork casings (large intestine). The blood sausages are cooked in boiling water for approximately half an hour. After cooking, the blood sausages are cooled and then drained hung.

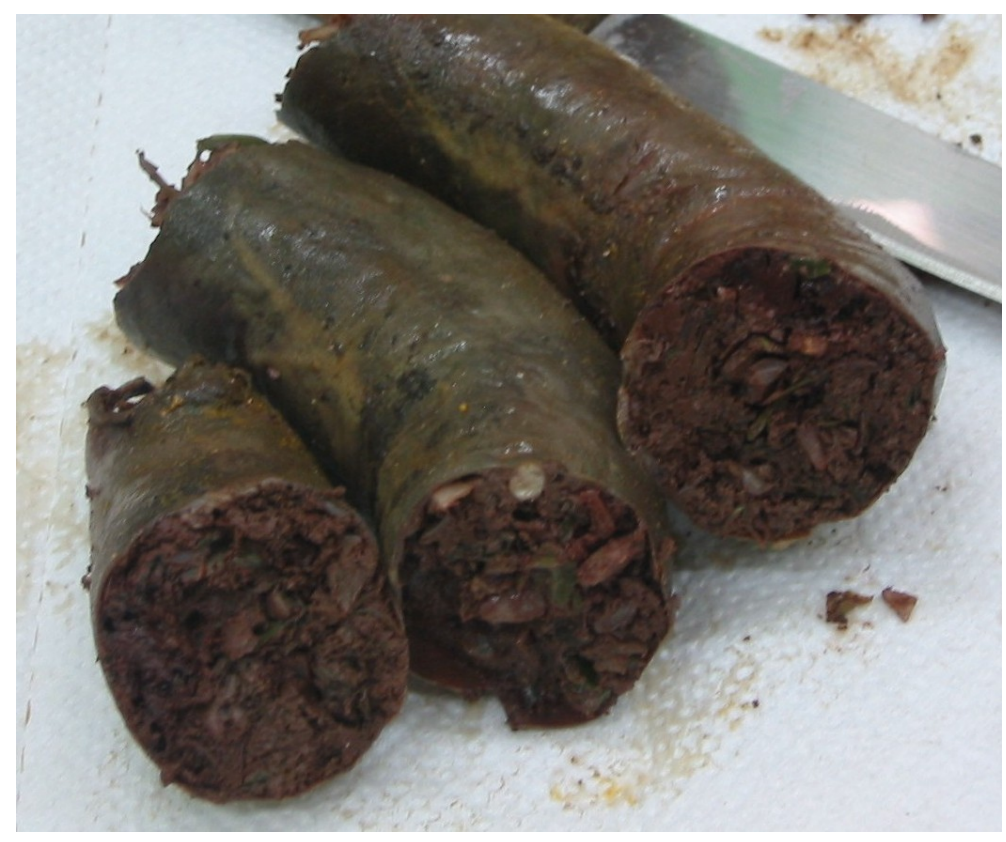

Figure 2. Peruvian blood sausage Relleno de Tumbes.

\subsection{Chemical composition}

\subsubsection{Proximate composition}

The proximate composition of Morcilla de Leon and Relleno de Tumbes are shown in Tables 3 and 4, respectively. Moisture is expressed as percentage of fresh weight, and values of protein, fat, available carbohydrate, fibre and ash as percentage of fresh and dry matter weights. Moisture content variability would mainly depend on fat content and the degree of drying loss during cooling and storage. Furthermore, the presence and variability of protein, fat, available carbohydrates and total dietary fibre would be respectively explained mainly by the amounts of blood, lard or tallow, rice or breadcrumbs, onion or cabbage (plus other vegetal condiments and species) used in the formulation. In fresh weight basis, both types of blood sausages have a similar percentage of moisture. However, Morcilla de Leon shows lower amount of protein and higher of fat, fibre and available carbohydrates, than Relleno de Tumbes, both in fresh and dry weight basis. This is explained by a higher amount of 
blood and lower of vegetables and fat, being used in the Relleno de Tumbes making process, with respect to those being used for Morcilla de Leon.

\begin{tabular}{lcc}
\hline & $\begin{array}{c}\text { Mean } \pm \text { SD } \\
\text { (\% fresh weight) }\end{array}$ & $\begin{array}{c}\text { Mean } \pm \text { SD } \\
\text { (\% of dry weight) }\end{array}$ \\
\hline Moisture & $67.1 \pm 5.8$ & - \\
\hline Protein & $5.2 \pm 0.9$ & $16.3 \pm 3.6$ \\
\hline Fat & $14.2 \pm 3.9$ & $42.9 \pm 7.6$ \\
\hline Ash & $1.9 \pm 0.1$ & $5.9 \pm 1.2$ \\
\hline Total dietary fibre & $3.4 \pm 1.5$ & $10.1 \pm 3.1$ \\
\hline Available carbohydrate & $8.2 \pm 3.4$ & $25.0 \pm 6.3$ \\
\hline
\end{tabular}

Table 3. Proximate composition of the Spanish blood sausage Morcilla de Leon $(n=8)$.

\begin{tabular}{lcc}
\hline & $\begin{array}{c}\text { Mean } \pm \text { SD } \\
\text { (\% of fresh weight) }\end{array}$ & $\begin{array}{c}\text { Mean } \pm \text { SD } \\
\text { (\% of dry weight) }\end{array}$ \\
\hline Moisture & $71.8 \pm 6.9$ & - \\
\hline Protein & $11.9 \pm 2.8$ & $42.4 \pm 10.2$ \\
\hline Fat & $9.4 \pm 4.0$ & $33.3 \pm 13.9$ \\
\hline Ash & $2.1 \pm 0.9$ & $7.6 \pm 3.2$ \\
\hline Total dietary fibre & $1.1 \pm 0.4$ & $3.9 \pm 1.3$ \\
\hline Available carbohydrate & $3.6 \pm 1.6$ & $13.8 \pm 6.3$ \\
\hline
\end{tabular}

Table 4. Proximate composition of the Peruvian blood sausage Relleno de Tumbes $(n=12)$.

\subsubsection{Mineral composition}

The mineral contents of Morcilla de Leon and Relleno de Tumbes are shown in Tables 5 and 6, respectively. Values (expressed as $\mathrm{mg} / 100 \mathrm{~g}$ ) are given in all fresh, dry and nonfat dry weight basis. $\mathrm{Na}$ is the mineral with the highest concentration, and the mean value seems slightly lower in Morcilla de León than in Relleno de Tumbes, where Na concentration shows a great variability between samples (high standard deviation). In average, Relleno de Tumbes contained higher amounts (approximately twice as much) of Ca and S macroelements and of $\mathrm{Fe}, \mathrm{Zn}$ and $\mathrm{Cu}$ microelements.

The mineral content of blood sausages is the result of the sum of the contributions from all the ingredients used. In order to better ascertain the eventual contribution of ingredients to the mineral content of blood sausages, the mineral composition of the main ingredients used in Morcilla de Leon and/or Relleno de Tumbes is shown Table 7 [16,41,48-50]. From Table 7 and taking into account the quantities of the ingredients used in the making processes of the 
blood sausages, it can be notice that blood appears to be the main source of Fe and $\mathrm{Cu}$ to blood sausages. On the other hand, onion and specially cabbage would be the main sources of K, Ca and Mn. Furthermore, S, P, Mg and Zn are importantly provided by both blood and vegetables, with the the high $\mathrm{S}$ content of cabbage being remarkable. Finally, lard seems not to be a good source of minerals and common salt, added at amounts of $1-2 \%$ to the sausage mixture, is the major source of $\mathrm{Na}$ in sausages (not shown in tables). In this context, the higher content of $\mathrm{Fe}$ and $\mathrm{Cu}$ in Relleno de Tumbes can be associated to the higher quantity of blood used. Similarly, the high content of $\mathrm{Ca}$ and $\mathrm{S}$ in cabbage together with the high quantity used in Relleno de Tumbes would account for the higher levels of those minerals with respect to Morcilla de Leon.

\begin{tabular}{lccc}
\hline & Fresh weight & Dry matter & Non-fat dry matter \\
\hline Macroelements & $623 \pm 131$ & & \\
\hline $\mathrm{Na}$ & $149 \pm 27$ & $1900 \pm 615$ & $3315 \pm 1038$ \\
\hline $\mathrm{K}$ & $76 \pm 9$ & $452 \pm 83$ & $795 \pm 121$ \\
\hline $\mathrm{S}$ & $45 \pm 13$ & $240 \pm 61$ & $402 \pm 101$ \\
\hline $\mathrm{P}$ & $29 \pm 8$ & $136 \pm 21$ & $146 \pm 36$ \\
\hline $\mathrm{Ca}$ & $15 \pm 2$ & $86 \pm 21$ & $78 \pm 16$ \\
\hline $\mathrm{Mg}$ & $48 \pm 9$ & $58.71 \pm 23.33$ \\
\hline $\mathrm{Microelements}$ & $10.96 \pm 3.30$ & & $1.88 \pm 0.41$ \\
\hline $\mathrm{Fe}$ & $0.37 \pm 0.12$ & $33.24 \pm 10.96$ & $1.00 \pm 0.18$ \\
\hline $\mathrm{Zn}$ & $0.20 \pm 0.05$ & $1.14 \pm 0.35$ & $0.42 \pm 0.12$ \\
\hline $\mathrm{Mn}$ & $0.08 \pm 0.02$ & $0.59 \pm 0.10$ & $0.26 \pm 0.05$ \\
\hline $\mathrm{Cu}$ & & & 160 \\
\hline
\end{tabular}

Table 5. Essential mineral content $(\mathrm{mg} / 100 \mathrm{~g})$ of the Spanish blood sausage Morcilla de Leon $(\mathrm{n}=8)$.

From the nutritional point of view, comparing the mineral content of blood sausages (fresh weight basis) with that of pork meat or muscle meat products, such as frankfurters or chorizos [16-51], the blood sausages had considerably higher levels of $\mathrm{Ca}$ (more than three times), and $\mathrm{Mn}, \mathrm{Fe}$ and $\mathrm{Cu}$ (more than ten times). On the contrary, amounts of $\mathrm{K}, \mathrm{P}, \mathrm{S}$ and $\mathrm{Zn}$ are slightly lower in blood sausages (up to $60 \%$ lower than those in meat). The levels of $\mathrm{Mg}$ were roughly comparable in meat and blood sausages, and those of $\mathrm{Na}$ depends on the quantities of common salt added. Having into account the Reference Labelling Values (RLVs) reported by the Scientific Committee of Food from the European Union [52], which are the following: K (2000 mg), Ca (1000 mg), P (700 mg), Na (600 mg), Mg (375 mg), Fe (14 $\mathrm{mg}), \mathrm{Zn}(10 \mathrm{mg}), \mathrm{Mn}(2 \mathrm{mg})$ and $\mathrm{Cu}(1 \mathrm{mg})$; interestingly, a portion of $100 \mathrm{~g}$ of blood sausage equals or exceeds the recommended daily intake of Fe and contributes with $10-15 \%$ the recommended daily intake of $\mathrm{Mn}$ and $\mathrm{Cu}$. Thus, the high iron content of blood, coupled with 
the high absorption of heme iron compared to non-heme iron, is particularly useful for food based strategies designed to combat iron deficiency anemia a major global malnutrition problem.

\begin{tabular}{lccc}
\hline & Fresh weight & Dry matter & Non-fat dry matter \\
\hline Macroelements & $706 \pm 335$ & & \\
\hline $\mathrm{Na}$ & $142 \pm 56$ & $2821 \pm 1343$ & $798 \pm 254$ \\
\hline $\mathrm{K}$ & $116 \pm 22$ & $565 \pm 223$ & $590 \pm 108$ \\
\hline $\mathrm{S}$ & $48 \pm 19$ & $411 \pm 102$ & $271 \pm 83$ \\
\hline $\mathrm{P}$ & $50 \pm 18$ & $190 \pm 67$ & $257 \pm 83$ \\
\hline $\mathrm{Ca}$ & $14 \pm 6$ & $180 \pm 65$ & $71 \pm 28$ \\
\hline $\mathrm{Mg}$ & $50 \pm 21$ & $146.50 \pm 36.81$ \\
\hline $\mathrm{Microelements}$ & $29.01 \pm 8.55$ & & $3.51 \pm 0.52$ \\
\hline $\mathrm{Fe}$ & $0.70 \pm 0.10$ & $101.03 \pm 25.39$ & $0.74 \pm 0.36$ \\
\hline $\mathrm{Zn}$ & $0.14 \pm 0.07$ & $2.44 \pm 0.51$ & $0.69 \pm 0.32$ \\
\hline $\mathrm{Mn}$ & $0.13 \pm 0.06$ & $0.52 \pm 0.25$ & $0.49 \pm 0.25$ \\
\hline $\mathrm{Cu}$ & & & \\
\hline
\end{tabular}

Table 6. Essential mineral content (mg/100 g) of the Peruvian blood sausage Relleno de Tumbes $(n=12)$

Results of principal component analysis are shown in Figures 3 and 4. Principal component analysis was carried out with the mineral content expressed as mg per $100 \mathrm{~g}$ of nonfat dry matter for all the blood sausages analysed in this study. The first principal component (factor 1) accounted for a variance of $42.77 \%$ and the second of $19.89 \%$. Figure 3 shows that samples from each type of blood sausage are located in two defined sets of results, which corroborate the differences in mineral contents found between both blood sausages. Figure 4 shows the projection of the variables (mineral contents) on the plane formed by the two principal components. The minerals with higher influence (factor loadings higher than 0.8) on factor 1 are $\mathrm{Mn}, \mathrm{Zn}$, and $\mathrm{Ca}$. The mineral with higher influence on factor 2 was $\mathrm{K}$ (factor loading $>0.8$ ).

Moreover, in Figure 4 it can be seen that the most correlated mineral contents, as indicated by the highest proximity of points in the plain, were $\mathrm{S}$ with $\mathrm{Ca}$ and $\mathrm{Mn}$ with $\mathrm{Zn}$. The first relation could be explained by the significant contribution of cabbage and onion to the $S$ and Ca content in the sausage mixture. However, the second relation is difficult to explain from the contribution of ingredients. Other remarkable correlation is that of $\mathrm{Fe}$ with $\mathrm{Cu}$, with blood being the main source of both of them. This correlation could be not as strong as expected due to the feasible migration of Fe ions to ingredients and sausage mixture from the surfaces of cast iron equipment, i.e., pans, knives, etc. [53], which are frequently present at 
small homemade sausage producing facilities in small villages. This reason could be responsible for part of the distance between the Fe and $\mathrm{Cu}$ points.

\begin{tabular}{lcccc}
\hline & Blood, pork & Pork fat & Onion & Cabbage \\
\hline Macroelements & 300 & 11 & 3 & 41 \\
\hline $\mathrm{Na}$ & 50 & 65 & 166 & 161 \\
\hline $\mathrm{K}$ & 140 & - & 51 & 300 \\
\hline $\mathrm{S}$ & 100 & 38 & 35 & 32 \\
\hline $\mathrm{P}$ & 7 & 2 & 22 & 53 \\
\hline $\mathrm{Ca}$ & 6 & 2 & 11 & 15 \\
\hline $\mathrm{Mg}$ & & & & 0.2 \\
\hline $\mathrm{Microelements}$ & 50 & 0.2 & 0.2 & 0.6 \\
\hline $\mathrm{Zn}$ & 0.5 & 0.4 & 0.2 & 0.2 \\
\hline $\mathrm{Mn}$ & 0.0 & 0.0 & 0.1 & 0.2 \\
\hline $\mathrm{Cu}$ & 0.7 & 0.0 & 0.0 \\
\hline
\end{tabular}

Table 7. Essential mineral content $(\mathrm{mg} / 100 \mathrm{~g}$ ) of the main ingredients used in Morcilla de Leon and/or Relleno de Tumbes

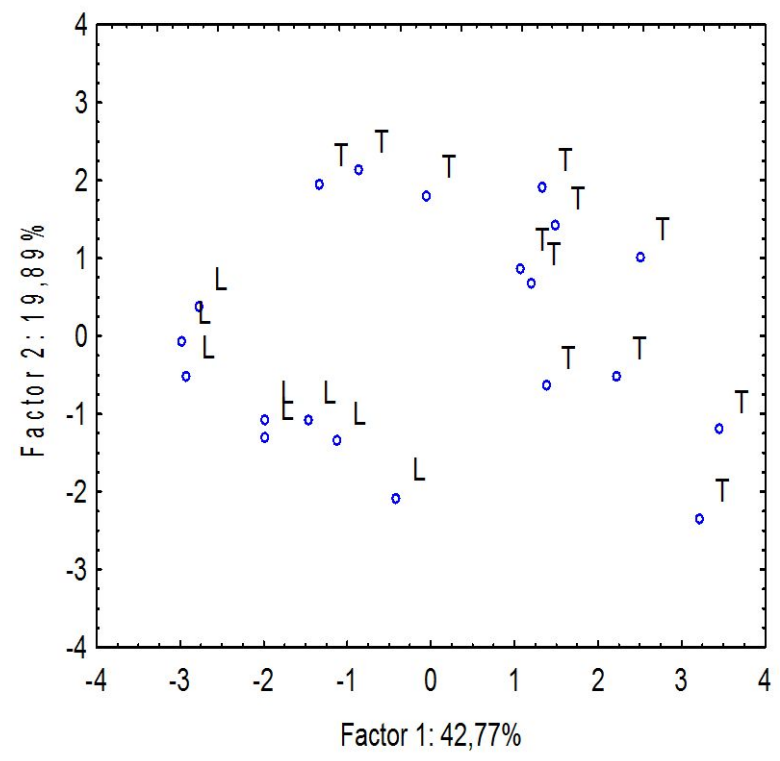

Figure 3. Principal component score plot (two first principal components or factors), considering mineral composition on non-fat dry matter basis, and showing samples according to sausage type: L, Morcilla de Leon; T, Relleno de Tumbes 


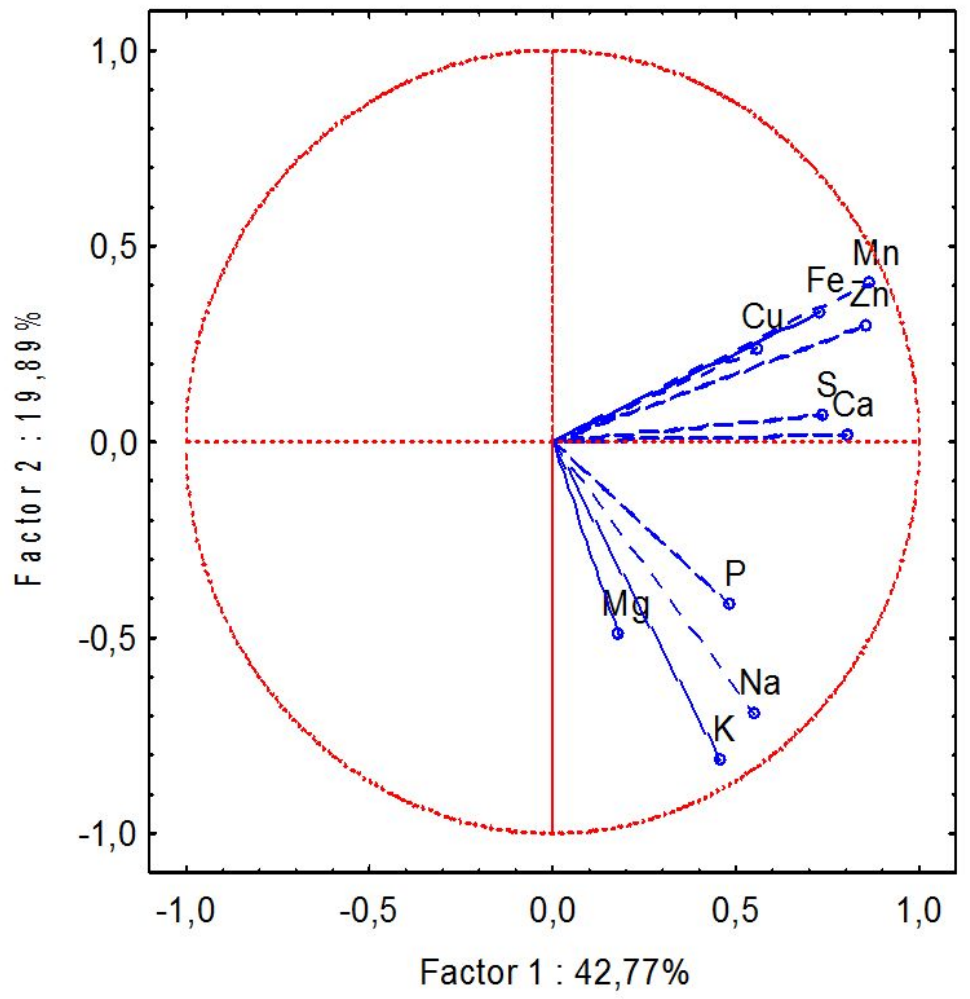

Figure 4. Projection of the normalised factor coordinates of variables (mineral contents) in the $1 \times 2$ factor plane obtained by the principal component analysis

\section{Conclusion}

The mineral content of two traditional blood sausages from different parts of the world: Morcilla de Leon and Relleno de Tumbes, as well as the proximate composition and general guidelines of the making process have been described in this study, which thus contribute to the chemical characterisation, diffusion and protection of these two traditional meat products.

The variety and quantities of ingredients used for blood sausage production have a significant relevance on their mineral content. Blood provides important quantities of $\mathrm{Fe}, \mathrm{Cu}$ and $\mathrm{Mn}$ to the blood sausages from the nutritional point of view. The content of Fe of $100 \mathrm{~g}$ of Morcilla de Leon practically equals the daily requirements for adults and that of Relleno de Tumbes exceeds those requirements. 


\section{Author details}

Daphne D. Ramos ${ }^{1}$, Luz H. Villalobos-Delgado ${ }^{3}$, Enrique A. Cabeza², Irma Caro, Ana Fernández-Diez ${ }^{4}$ and Javier Mateo ${ }^{4}$

*Address all correspondence to: jmato@unileon.es

1 Faculty of Veterinary Medicine, Universidad Nacional Mayor de San Marcos, Lima, Peru

2 Department of Microbiology, University of Pamplona, Pamplona, Colombia

3 Institute of Agroindustry, Technological University of the Mixteca, Oaxaca, Mexico

4 Department of Food Hygiene and Technology, University of León, Campus León, Spain

\section{References}

[1] Millikan M. Nutritional Metals in Foods by AAS. In: Akhyar FM. (ed.) Atomic Absorption Spectroscopy. Rijeka: Intech; 2012. p143-166. Available from http:// www.intechopen.com/books/atomic-absorption-spectroscopy/comparative-assessment-of-the-mineral-content-of-a-latin-american-raw-sausage-made-by-traditional-or (accessed 10 September 2012).

[2] Castro FMM, Morgano MA, Nascimiento de Queiroz SC, Mantovani MDB. Relationships of the Minerals and Fatty Acid Contents in Processed Turkey Meat Products. Food Chemistry 2000; 69: 259-265.

[3] Cabrera MC, Ramos A, Saadoun A, Brito G. Selenium, Copper, Zinc, Iron and Manganese Content of Seven Meat Cuts from Hereford and Braford Steers Fed Pasture in Uruguay. Meat Science 2000; 84: 518-528.

[4] Decker AE, Park Y. Healthier Meat Products as Functional Foods. Meat Science 2010; 86: 49-55.

[5] McNeill S, Van Elswik ME. Red Meat in Global Nutrition. Meat Science 2012; 92, 166-173.

[6] Nasreddine L, Parent-Massin D. Food Contamination by Metals and Pesticides in the European Union. Should We Worry?. Toxicology Letters 2002; 127, 29-41.

[7] Grembecka M, Malinowska E, Szefer P. Differentiation of Market Coffee and its Infusions in View of their Mineral Composition. Science of the Total Environment 2007; 383, 59-69.

[8] Kelly SD, Bateman AS. Comparison of Mineral Concentrations in Commercially Grown Organic and Conventional Crops - Tomatoes (Lycopersicon esculentum) and Lettuces (Lactuca sativa). Food Chemistry 2010; 119, 738-745. 
[9] Luykx DMAM, Van Ruth SM. An Overview of Analytical Methods for Determining the Geographical Origin of Food Products. Food Chemistry 2008; 107, 897-911.

[10] Sun S, Guo B, Wei Y, Fan M. Multi-element Analysis for Determining the Geographical Origin of Mutton from Different Regions of China. Food Chemistry 2011; 124, 1151-1156.

[11] Barnes KW, Debrah E. Determination of Nutrition Labeling Education Act. Minerals in Foods by Inductively Coupled Plasma-Optical Emission Spectroscopy. Atomic Spectroscopy 1997; 18, 41-54. Available from http://shop.perkinelmer.com.cn/ Content/RelatedMaterials/Articles/atl_barnesfoodatomicspec.pdf (accessed $10 \mathrm{Sep}$ tember 2012).

[12] Gupta PA, Gupta S. Elemental Profiling: Its Role and Regulations. In: Akhyar FM. (ed.) Atomic Absorption Spectroscopy. Rijeka: Intech; 2012. p37-60. Available from http://www.intechopen.com/books/atomic-absorption-spectroscopy/comparative-assessment-of-the-mineral-content-of-a-latin-american-raw-sausage-made-by-traditional-or (accessed 10 September 2012).

[13] Ibáñez E, Cifuentes A. New Analytical Techniques in Food Science. Critical Reviews in Food Science and Nutrition 2001; 41, 413-450.

[14] Jimenez-Colmenero F, Pintado T, Cofrades S, Ruiz-Capillas C, Bastida S. Production Variations of Nutritional Composition of Commercial Meat Products. Food Research International 2010; 43, 2378-2384.

[15] Toldrá F, Reig M. Innovations for Healthier Processed Meats. Trends in Food Science and Technology 2011; 22, 517-522.

[16] USDA. USDA National Nutrient Database for Standard Reference, Release 24, U.S. Department of Agriculture, Agricultural Research Service; 2012 http:// ndb.nal.usda.gov/ (accessed 10 September 2012).

[17] Davidson A. The Oxford Companion to Food. UK, Oxford University Press; 2011.

[18] Guha A, Guha R, Gera S. Study on the Alteration of Bubaline Blood Biochemical Composition Owing to Slaughter. African Journal of Biotechnology 2012; 11, 12134-12137.

[19] Liu DC, Ockerman HW. Meat Co-Products. In: Hui YH, Nip W, Rogers RW, Young OA. (eds.) Meat Science and Applications. New York: Marcel Dekker; 2001.

[20] Toldrá F, Aristoy MC, Mora L, Reig M. Innovations in Value-Addition of Edible Meat by-Products. Meat Science 2012; 92, 290-296.

[21] Mateo J, Cabeza EA, Zumalacárregui JM. Bases de la Tecnología de los Embutidos de Sangre. In: Pérez-Álvarez JA, Fernández-López J, Sayas-Barberá E. (eds.) Industrialización de Productos de Origen Animal (Vol. 1). Orihuela, España: Escuela Politécnica Superior de Orihuela. Universidad Miguel Hernández; 2007, p215-242. 
[22] Ofori JA, Hsieh YHP. Blood-Derived Products for Human Consumption. Revelation and Science 2011; 1, 14-21.

[23] Diez MA, Jaime I, Rovira J. The influence of Different Preservation Methods on Spoilage Bacteria Populations Inoculated in Morcilla de Burgos During Anaerobic Cold Storage. International Journal of Food Microbiology 2009; 132, 91-99.

[24] Feiner G. Meat Products Handbook: Practical Science and Technology. Cambridge: Woodhead Publishing Ltd; 2006.

[25] Mateo J, Caro I, Figueira AC, Ramos D, Zumalacárregui JM. Meat Processing in Ibero-American Countries: a Historical View. In: Noronha VT, Nijkamp P, Rastoin JL. (eds.) Traditional Food Production and Rural Sustainable. A European challenge. Surrey, UK: Ashgate Publishing Ltd; 2008. p121-134.

[26] Choi YS, Choi JH, Han DJ, Kim HY, Lee MA, Kim HW, Lee CH, Paik HD, Kim CJ. Physicochemical and Sensory Characterization of Korean Blood Sausage with Added Rice Bran Fiber. Korean Journal of Food Science and Animal Resources 2009; 29, 260-268.

[27] Diez AM, Santos EM, Jaime I, Rovira J. Effectiveness of Combined Preservation Methods to Extend the Shelf Life of Morcilla de Burgos. Meat Science 2009; 81, 171-177.

[28] Dehmer NA. La Formación Profesional de los Carniceros y Fabricantes de Embutidos. Guatemala: Instituto Técnico de Capacitación y Productividad - Centro de Capacitación en Tecnología de la Carne; 1995.

[29] Reichert JE. Tratamiento Térmico de los Productos Cárnicos. Zaragoza, España: Acribia; 1988.

[30] Stiebing A. Tecnología de la Morcilla. Fleischwirtsch. Español 1992; 1, 13-20.

[31] Wirth F. Tecnología de los Embutidos Escaldados. Zaragoza, España: Acribia; 1992.

[32] Frentz JC, Migaud M. (1976). La Charcuterie Cuite. Généralités et Techniques Actuelles. Vesoul, France: Soussana Editeur; 1976.

[33] Luzón-Merino F, Martín-Bejarano S. Fabricación de Productos Cárnicos Tratados por el Calor - Morcillas Cocidas. In: Martín S. (ed.) Enciclopedia de la Carne y los Productos Cárnicos. Plasencia, España: Ediciones Martín \& Macias; 2001. p1431-1458.

[34] Schiffner E, Oppel K, Lörtzing D. Elaboración Casera de Carne y Embutidos. Zaragoza, España: Acribia; 1996.

[35] Cattaneo P, Bonandrini E. "La Morcela de Arroz". Origine - Caratteristiche e Tecnologia di Produzione di un Tipico Insaccato di Sangue Portoghese. Ingegneria Alimentare de le Conserve Animali 1998; 14, 18-27. 
[36] Santos EM, González C, Jaime I, Rovira J. Physicochemical and Sensory Characterisation of Morcilla de Burgos, a Traditional Spanish Blood Sausage. Meat Science 2003; 65, 893-898.

[37] CIC. Le Boudin Noir. Paris : Paris, Francia: Centre d'Information sur les Charcuteries ; 2003. http://www.infocharcuteries.fr/dmdocuments/dossier_synthese_boudins.pdf (accessed 10 September 2012)

[38] Souci SW, Fachmann W, Kraut H. Sausages and Pastries. Food Composition and Nutrition Tables. Stuttgart, Germany: Wissenschaftliche Verlagsgesellschaft mbH; 1989.

[39] Frey W. Fabricación Fiable de Embutidos. Zaragoza, España: Acribia; 1985.

[40] Martin G, Wert R, Vigili L, Perianes J, Mancilla C, Aza M. Tabla de Composición de Alimentos de la Sociedad Española de Nutrición Básica Aplicada - SENBA; 2005 http://www.5aldia.org/v_5aldia/apartados/apartado.asp?te=179 (accessed 5 March 2008)

[41] KTL (2011). Finnish Food Composition Database, Release 14. National Public Health Institute of Finland, Nutrition Unit; 2011. http://www.fineli.fi/foodlist.php?foodname $=\mathrm{B} \% \&$ lang=en (accessed 10 September 2012)

[42] Saxholt E, Christensen AT, Møller A, Hartkopp HB, Hess Ygil K. Hels OH. Danish Food Composition Databank, ed. 7.01. Denmark: Department of Nutition, Danish Food Institute - Technical University of Denmark; 2012. http://www.foodcomp.dk/ (accessed 10 September 2012).

[43] Bunger A, Alessandri T, Vinagre J, Wittig E, López L. Formulación y Estudio de Embutidos Cárnicos en Envases Flexibles Esterilizables: Morcillas de Sangre. Fleischwirtschaft Español 1992; 2, 15-18.

[44] FAO/LATINFOODS. Tabla de Composición de Alimentos de América Latina. Santiago de Chile: FAO, Oficina Regional Para Latinoamérica y el Caribe; 2009. http:// www.rlc.fao.org/es/conozca-fao/que-hace-fao/estadisticas/composicion-alimentos (accessed 10 September 2012)

[45] Alcaide E, Gómez R, Carmona, MA, Fernández J. Estudio de los Elementos Minerales en Productos Cárnicos. Alimentaria 1995; 262, 63-67.

[46] AOAC. Official Methods 920.153 Ash, 950.46 Moisture, 981.10 Crude Protein, and 991.36 Fat (Crude) Contents in Meat and Meat Products, and 985.29 Total Dietary Fiber in Foods, Enzymatic-Gravimetric Method. In: Cunniff, P. (ed.) Official Methods of Analysis of the AOAC International (Vol. II, 16th ed.). Gaithersburg, MD: AOAC; 1999.

[47] StatSoft Inc. STATISTICA (Data Analysis Software System), Version 6. 6. 2001. www.statsoft.com 
[48] Collazos C, Alvistur E, Vasquez J. Tablas peruanas de composición de alimentos, Séptima edición. Lima, Peru: Centro Nacional de Alimentación y Nutrición, Instituto Nacional de Consumo; 1996.

[49] Gorbatov VM. Collection and Utilization of Blood and Blood Proteins for Edible Purposes in the URRS. In: Pearson AM, Dutson TR. (eds.) Edible Meat By-products, Advances in Meat Research, 5. Essex, UK: Elsevier Science Publishers LTD; 1988. p167-196.

[50] Rodrigues AS, Fogliano V, Graziani G, Mendes S, Vale AP, Conçalves C. Nutritional Value of Onion Regional Varieties in Northwest Portugal. Electron Journal of Environmental Agricultural Food Chemistry 2003; 2, 519-524.

[51] Gonzalez-Tenorio, R, Fernández-Díez A, Caro I, Mateo J. Comparative Assessment of the Mineral Content of a Latin American Raw Sausage Made by Traditional or NonTraditional Processes. In: Akhyar FM. (ed.) Atomic Absorption Spectroscopy. Rijeka: Intech; 2012. p167-182. Available from http://www.intechopen.com/books/atomic-absorption-spectroscopy/comparative-assessment-of-the-mineral-content-of-a-latinamerican-raw-sausage-made-by-traditional-or (accessed 10 September 2012).

[52] SCF (Scientific Committee on Food). Opinion of the Scientific Committee on Food on the revision of reference values for nutrition labelling. SCF/CS/NUT/ GEN/18 Final. Bruxelles/Brussels, Belgium: European Commission Health \& Consumer Protection Directorate-General; 2003.

[53] Quintaes KD, Amaya-Farfan J, Tomazini FM, Morgano MA, Mantovani DMB. Mineral Migration from Stainless Steel, Cast Iron and Soapstone Pans (Steatite) onto Food Simulants. Ciência e Tecnologia de Alimentos 2004; 24, 397-402. 
